\title{
A-Kinase Anchor Protein 2
}

National Cancer Institute

\section{Source}

National Cancer Institute. A-Kinase Anchor Protein 2. NCI Thesaurus. Code C158486.

A-kinase anchor protein 2 (859 aa, $295 \mathrm{kDa}$ ) is encoded by the human AKAP2 gene. This protein is involved in the modulation of protein kinase A activity. 